\title{
Exploring Factors Influencing Internationalization of TPL Service Providers: Evidences From Turkey ${ }^{1}$
}

\section{Tuğçe DANACI ÜNAL iD a Selami ÖZCAN iD $b$}

a Manisa Celal Bayar University, Faculty of Applied Sciences, Department of International Trade, Manisa, Turkey.

b Yalova University, Faculty of Economics and Administrative Science, Department of Business Administration, Yalova, Turkey.

\begin{tabular}{ll}
\hline ARTICLE INFO & ABSTRACT \\
\hline Keywords: & $\begin{array}{l}\text { Purpose - This study aims to determine the factors affecting operational and managerial decisions } \\
\text { related to the internationalization process of Third-Party Logistics (TPL) service providers operating } \\
\text { TPL }\end{array}$ \\
in Turkey. \\
Dervices Export \\
$\begin{array}{l}\text { International Logistics } \\
\text { Internationalization }\end{array}$ \\
Pervice Marketing \\
a business depends on its own OLI (ownership-O, location-L, and internalization-I) advantages. The \\
conceptual model of the study was set by grouping these advantages (factors) obtained from a \\
comprehensive literature review and expert decisions. A questionnaire form was structured subject \\
to the network structure of the factors in this model. Data collected from survey forms filled in by \\
Received & $\begin{array}{l}\text { 31 logistics experts, were analyzed by using Analytical Network Process (ANP). } \\
\text { Revised }\end{array}$ \\
Accepted & $\begin{array}{l}\text { Findings - The results of the study reveal that the most important factors influencing the } \\
\text { internationalization process of TPL service providers are political factors, economic factors, cultural } \\
\text { factors and long-term relationships respectively. However, the least effective ones were determined } \\
\text { as the number of vehicles, number of employees and market saturation. }\end{array}$ \\
Article Classification: & $\begin{array}{l}\text { Discussion - The fact that the first three sub-factors are involved in market factors supports that } \\
\text { long-term international logistics activities depend on long-term and stable political and economic } \\
\text { relations. Secondly, we argue that a good international logistics process management is carried out } \\
\text { thanks to a good international management mentality and technological infrastructure based on } \\
\text { developed computer and tracking systems. Additionally, customers focus on the quality of service } \\
\text { and how easy they reach the information rather than the number of vehicles or employees. We } \\
\text { assume that this study is one of the few studies on the subject and the findings will contribute to } \\
\text { both academic and sectoral environment. Since this study is limited to TPL service providers } \\
\text { operating in Turkey, the results of the study can be improved by future studies concerning different } \\
\text { service providers operating in different regions. }\end{array}$ \\
&
\end{tabular}

\section{INTRODUCTION}

Over the last several decades the unique characteristics of services have been the subject of many studies. Initial approaches have involved specifying these hallmarks as intangibility, inseparability, heterogeneity and perishability (Zeithaml et al., 1985). However, developments in information technologies have emphasized services by enabling internet usage to become widespread, information to be easily accessed and customers to become a part of the production. Accordingly, new characteristics were introduced to the concept of services within the framework of Service Dominant $(S-D)$ Logic which considers the services with operant resources such as knowledge, skills and customers (Vargo and Lusch, 2004). More than focusing on customer demands and needs, services are now part of a system that involves the co-production and value creation. Thus, the features such as knowledge-intensive, people-centered, intangible and customized are included in distinctive

\footnotetext{
${ }^{1}$ This study was derived from Tuğçe Danacı Ünal's doctoral dissertation titled "Factors Affecting Internationalization Process of Third Party Logistics Companies" conducted under the supervision of Prof. Dr. Selami Özcan at Yalova University, Institute of Social Sciences. Doctoral dissertation was supported by Yalova University Scientific Research Projects Coordination Unit [project number: 2017 / DR / 0004] and the Tuğçe Danacı Ünal's TÜBİTAK 2211-A Scholarship Program.
}

\section{Suggested Citation}

Danacı Ünal, T., Özcan, S. (2020). Exploring Factors Influencing Internationalization of Tpl Service Providers: Evidences From Turkey, İşletme Araştırmaları Dergisi, 12 (4), 3991-4004. 


\section{T. Danacı Ünal - S. Özcan 12/4 (2020) 3991-4004}

characteristics of today's professional services (Netland and Alfnes, 2007). These distinctive features will lead the internationalization of services differently from that of tangible goods.

The rationale of the factors affecting the internationalization of services mainly focuses on (1) service related factors, (2) firm related factors, (3) market related factors and (4) networks related factors. Service related factors concerns the quality and diversity of services. Service quality refers to a measurement of how much the customer expectations meet the service performance, and that is more difficult to evaluate compared to the tangible goods (Parasuraman et al., 1985). Parasuraman et al. (1985) reveal ten factors for evaluating the service quality: reliability (dependability), responsiveness (timeliness), competence (knowledge and skill), access (ease of contact), courtesy (politeness, respect, and friendliness), communication (speaking simply and plainly), credibility (honesty, company name, reputation), security (physical safety, financial security), understanding/knowing the customer (needs and specific requirements) and tangibles (physical evidence). Service diversity on the other hand is a considerable factor for determining the foreign market entry behaviors in the service sector (Erramilli, 1990). Firm related factors are discussed by Javalgi and Martin (2007) as firm characteristics, management characteristics, firm level resources. They also indicate the importance of host country factors include cultural, political, technological, economic and market factors and how they affect on internationalization of services. However, such particularly market centered drivers as government regulations, face-to-face communication, language and cultural factors can also be key barriers to the internationalization of services and a firm uses networks for overcoming these obstacles (Freeman and Sandwell, 2008). Therefore, networks of the firm play a significant role in the internationalization process and market entry mode of the services (Coviello and Martin, 1999).

Studies related to factors on the internationalization of logistics services show similarities with the services in general. Logistics services are managed, delivered and controlled by Third Party Logistics (TPL) providers on behalf of the consigner (Hertz and Alfredsson, 2003:140). Studies state that the internationalization of the logistics services conducted by TPL providers depends on various factors. Most analyzed drivers are (1) Networks (Hertz, 1993; Hertz and Alfredsson 2003; Lommelen et al., 2002; Lemoine and Dagnæs, 2003; Rahman et al., 2019); (2) Infrastructure (Mitra and Bagchi, 2008; Rahman et al., 2019); (3) Information technologies (Mitra and Bagchi, 2008; Rahman et al., 2019); (4) Rules and practices (Hertz, 1993; Mitra and Bagchi, 2008); (5) Customers and trust (Hertz, 1993; Hertz and Alfredsson 2003).

This study considers the problem from a broad perspective. It aims to determine the factors affecting operational and managerial decisions related to the internationalization process of TPL service providers operating in Turkey. In this context, the research questions of the study were determined as: (1) What are the factors that affect the TPL service providers to enter international markets? (2) What are the obstacles that prevent TPL service providers to enter international markets? (3) What are the factors affecting the competitiveness of the TPL service providers' strategies in international operations? (4) What are the degree of importance of these factors and (5) How do these factors affect each other? Moreover, a model is developed depending on theory and expert decisions in order to identify the factors and their interactions.

\section{THEORETICAL BACKGROUND AND CONCEPTUAL MODEL}

Most of the studies concerning the internationalization of services are commonly based on foreign direct investment (FDI) theories such as resource-based view (Brock and Alon, 2009; Javalgi and Grossman, 2014); transaction cost approach (Erramilli, 1990), network theory (Hertz and Alfredsson, 2003) and internalization theory (Boehe, 2016). Unlike many studies, theoretical background of this study is based on Eclectic Paradigm, one of the internationalization approaches related to FDI. The concept of "eclectic" compiled from various systems as a word meaning, gave its name to the model developed by Dunning (1988). Dunning (1988) explained the underlying reason for his preference for eclectic as the necessity that these activities should be based on several theories of economic theory in order to fully explain the international activities of enterprises. In general, the eclectic paradigm can be said to incorporate many approaches such as internalization theory and transaction cost theory. The paradigm seeks answers to why (motive and reasons), where (location), and how (manner) questions about the international operations of multinational companies (Ferreira et al., 2011). According to this theory, the enterprise will be able to invest directly in the country depending on its own OOwnership advantages, L-Location advantages and I-Internalization advantages. These superlatives are called OLI advantages as a combination of their initials. The advantages of ownership $(\mathrm{O})$, called competitive or 


\section{T. Danacı Ünal - S. Özcan 12/4 (2020) 3991-4004}

monopolistic advantages, are patents and trademarks, market access, international arbitraging, etc.; location advantages (L) related to transport costs, production costs, tariff barriers, incentives, psychic distance, etc.; the advantages of internalization (I) can be exemplified as avoidance of buyer uncertainty, price discrimination, avoidance of property right infringement, etc. (Dunning, 1988).

Figure 1 shows the Conceptual Model of this study. It was created in accordance with the eclectic paradigm within the framework of data obtained from the literature and expert decisions. Depending on the theory, TPL providers will be able to operate in foreign markets based on their own O-Ownership advantages, L-Location advantages and I-Internalization advantages.

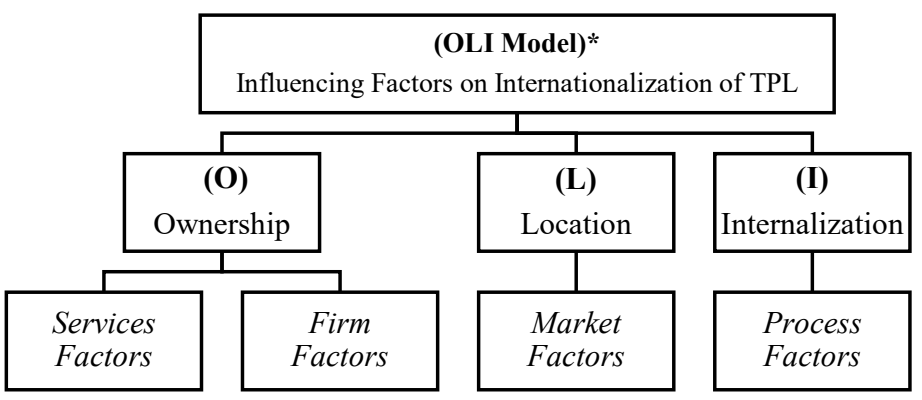

Figure 1. Conceptual Model

*Based on OLI Model by Dunning (1988)

Source: own work

The research model consists of three dimensions. These have been identified as the ownership advantages, location advantages, and internalization advantages with respect to the Dunning eclectic paradigm. In the model, the dimensions are adapted to the service sector. Ownership dimension is divided into two groups: services factors and firm factors. Location dimension covers factors related to the domestic and international market factors. Internalization dimension includes the process factors which play roles in internalizing the business's knowledge and experience.

\section{METHODOLOGY}

\subsection{Sample and Data Collection}

The research population of this study was determined as international TPL providers operating in Turkey. In order to find out international logistics behaviors of TPL providers, a sample of experts working in international logistics operations was selected using judgmental sampling method. Reasons for using the judgmental sampling method in this study are: (1) research sample is considered to best represent the population in terms of quality and quantity, (2) the limited number of qualified logistics experts, (3) difficulty in reaching experts, (4) intensive work programs of experts, (5) due to the long questionnaire, experts need to be meticulous and careful. Data was collected from expert decisions and questionnaire forms within the years 2017 and 2018. These forms were sent to 96 experts working in international logistics operations in different TPL providers via e-mail and hand delivery. 34 of these forms were returned and three were not included in the analysis due to inaccurate and missing data. The remaining 31 questionnaire forms, accepted adequate in number for research methodology (ANP), were analyzed in the study. Table 1 shows information regarding the descriptive statistics of the research sample. 
T. Danacı Ünal - S. Özcan 12/4 (2020) 3991-4004

Table 1. Descriptive Statistics of the Research Sample

\begin{tabular}{|c|c|c|c|c|c|c|}
\hline $\begin{array}{c}\text { Experts } \\
\text { (E) }\end{array}$ & Sector & Transportation Field & Position & Age & Education & $\begin{array}{c}\text { Experience } \\
\text { (Year) }\end{array}$ \\
\hline E1 & Int. Logistics & Airway & director & $36-40$ & graduate & $11-15$ \\
\hline E2 & Int. Logistics & Airway & authorized & $21-25$ & undergraduate & $1-5$ \\
\hline E3 & Int. Logistics & Airway & authorized & $36-40$ & high school & $11-15$ \\
\hline E4 & Int. Logistics & Airway & authorized & $31-35$ & undergraduate & $11-15$ \\
\hline E5 & Int. Logistics & Airway & director & $31-35$ & undergraduate & $11-15$ \\
\hline E6 & Int. Logistics & Airway & authorized & $41-45$ & high school & $16-20$ \\
\hline E7 & Int. Logistics & Airway & authorized & $41-45$ & high school & $21-25$ \\
\hline E8 & Int. Logistics & Airway & director & $\geq 46$ & high school & $\geq 26$ \\
\hline E9 & Int. Logistics & Airway & authorized & $21-25$ & undergraduate & $01-05$ \\
\hline E10 & Int. Logistics & Road & authorized & $21-25$ & undergraduate & $01-05$ \\
\hline E11 & Int. Logistics & Road & authorized & $26-30$ & undergraduate & $06-10$ \\
\hline E12 & Int. Logistics & Road & director & $26-30$ & undergraduate & 01-05 \\
\hline E13 & Int. Logistics & Road & director & $36-40$ & undergraduate & $11-15$ \\
\hline E14 & Int. Logistics & Road & authorized & $21-25$ & undergraduate & 01-05 \\
\hline E15 & Int. Logistics & Road & authorized & $36-40$ & associate degree & $11-15$ \\
\hline E16 & Int. Logistics & Road & authorized & $41-45$ & undergraduate & $16-20$ \\
\hline E17 & Int. Logistics & Road & director & $36-40$ & graduate & $11-15$ \\
\hline E18 & Int. Logistics & Road & authorized & $\geq 46$ & undergraduate & $21-25$ \\
\hline E19 & Int. Logistics & Seaway & director & $41-45$ & undergraduate & $16-20$ \\
\hline E20 & Int. Logistics & Seaway & director & $\geq 46$ & high school & $21-25$ \\
\hline E21 & Int. Logistics & Seaway & authorized & $21-25$ & undergraduate & $01-05$ \\
\hline E22 & Int. Logistics & Seaway & authorized & $36-40$ & undergraduate & $06-10$ \\
\hline E23 & Int. Logistics & Seaway & authorized & $26-30$ & undergraduate & 01-05 \\
\hline E24 & Int. Logistics & Seaway & director & $\geq 46$ & undergraduate & $\geq 26$ \\
\hline E25 & Int. Logistics & Seaway & director & $36-40$ & graduate & $11-15$ \\
\hline E26 & Int. Logistics & Seaway & authorized & $26-30$ & graduate & 01-05 \\
\hline E27 & Int. Logistics & Seaway -Road & authorized & $26-30$ & graduate & 01-05 \\
\hline E28 & Int. Logistics & Seaway -Road & director & $\geq 46$ & undergraduate & $16-20$ \\
\hline E29 & Int. Logistics & Seaway -Road & authorized & $31-35$ & associate degree & $06-10$ \\
\hline E30 & Int. Logistics & Seaway -Road & authorized & $36-40$ & graduate & $16-20$ \\
\hline E31 & Int. Logistics & Seaway -Road-Airway & director & $31-35$ & undergraduate & $06-10$ \\
\hline
\end{tabular}

\subsection{Research Methodology}

In this study, both qualitative and quantitative research methods are used together to obtain more valid and reliable results in solving the research problem. Firstly, it is aimed to find out the factors and the relations between these factors with the results obtained through the literature and expert decisions by using categorical analysis of the content analysis methods. Content analysis is one of the qualitative research methods used to reach common concepts and themes in a discourse. It is completed in four stages: coding data, finding themes, editing codes and themes, and finally defining and interpreting the findings (Yildırım and Şimşek, 2011: 228). In this study, coding which is one of the important stages of content analysis, was made according to the theories related to the subject previously described. Therefore, coding and creation of themes (Table 2) were designed in accordance with the conceptual model and these themes were used for structuring appropriate survey forms for the quantitative analysis.

In the quantitative research part of the study, Analytic Network Process (ANP) is used for determining the importance of the factors (themes) since it is the best method to analyze and sort the factors according to their degree of influence by taking into account their interactions. ANP is one of the most commonly used multicriteria decision methods developed by Thomas L. Saaty. Unlike Analytic Hierarchy Process (AHP), ANP is represented by a network and considers the dependence between the elements of the hierarchy (Saaty and Vargas, 2013). ANP aims to answer the questions (1) Which of two elements is more effective with respect to a given criterion, (2) Which of two elements affects a third element more with respect to a given criterion (Saaty, 2004). Accordingly, ANP is used in this study to find out not only the importance (degree of influence) of the factors in a hierarchic structure but also their relations within the structure. 


\section{T. Danacı Ünal - S. Özcan 12/4 (2020) 3991-4004}

Another crucial issue related to ANP is to form a group decision from decisions made by different experts. The most appropriate way has been proved to be the geometric mean of all individuals' decisions (Saaty and Vargas, 2006: 23).

Applied ANP steps proposed by Saaty (1999, 2004); Saaty and Vargas (2013) and Saaty and Sodenkamp (2008) are as follows:

Step 1: Defining the decision problem

Step 2: Determining the control hierarchy, criteria and subcriteria

Step 3: Performing paired comparisons

Step 4: Determining Priority Vectors and Calculating Consistency Ratio (CR) by using equations (1), (2) and (3) respectively.

$$
\begin{aligned}
& \begin{array}{lll}
A_{1} & \ldots & A_{n}
\end{array}
\end{aligned}
$$

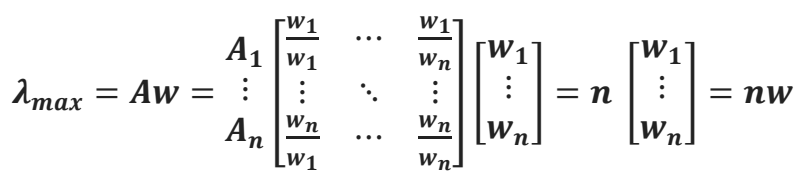

$$
\begin{aligned}
& (\boldsymbol{C I})=\left(\lambda_{\max }-\boldsymbol{n}\right) /(\boldsymbol{n}-\mathbf{1}) \\
& C R=C I / R I(\text { Random Consistency Index })
\end{aligned}
$$

Step 5: Constructing the Supermatrix by using equation (4)

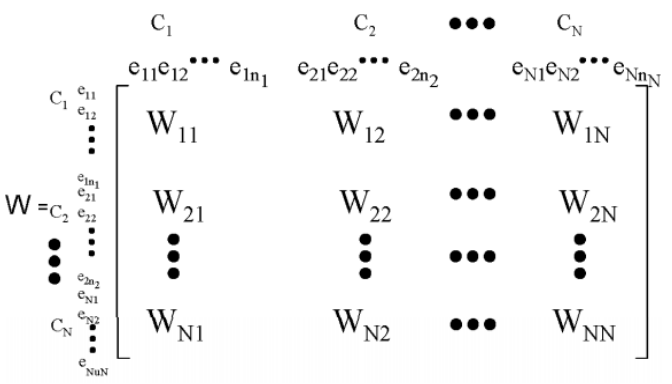

Step 6: Calculating the Limit supermatrix by using equation (5) or equation (6) (If the supermatrix has the cyclicity effect) (Tzeng and Huang, 2011)

$\lim _{k \rightarrow \infty}(W)^{k}$

$\lim _{k \rightarrow \infty}\left(\frac{1}{N}\right) \sum_{r=1}^{N} W_{r}^{k}$

Step 7: Obtaining the factors' degree of influence (importance) from the columns of the limit supermatrix.

\subsection{Application of Research Methods}

Step 1: Defining the decision problem

Decision problem has been defined previously as determining the most influential factors affecting the internationalization processes of TPL providers by considering the interactions among them.

Step 2: Determining the control hierarchy, criteria and subcriteria

The factors obtained from literature and experts decisions were categorized subject to the eclectic paradigm by using categorical analysis. Coding the factors, sub-factors and determining interdependencies between them were handled with different experts and consensus was established in the creation of themes, subthemes and network structure of the control hierarchy (Table 2, Figure 2). 
Table 2. Coding Factors and Sub-factors

\begin{tabular}{|c|c|c|}
\hline Main category* & Factors (Themes) & Sub-factors (Subthemes) \\
\hline \multirow{20}{*}{ Ownership (O) } & \multirow{9}{*}{ Services } & Price (f1) \\
\hline & & Reliability (f2) \\
\hline & & Service capacity (f3) \\
\hline & & Differentiation (f4) \\
\hline & & Specialization (f5) \\
\hline & & Speed (f6) \\
\hline & & Traceability (f7) \\
\hline & & Customer focus (f8) \\
\hline & & Timeliness (f9) \\
\hline & \multirow{11}{*}{ Firm } & Number of vehicles (f10) \\
\hline & & Financial infrastructure (f11) \\
\hline & & Physical infrastructure (f12) \\
\hline & & Business image (f13) \\
\hline & & Business experience (f14) \\
\hline & & Business specific value (f15) \\
\hline & & Logistics network (f16) \\
\hline & & Staff characteristics (f17) \\
\hline & & Technological infrastructure(f18) \\
\hline & & Managers characteristics (f19) \\
\hline & & Number of employees (f20) \\
\hline \multirow{9}{*}{ Location (L) } & \multirow{9}{*}{ Market } & Government supports (f21) \\
\hline & & Additional liabilities (f22) \\
\hline & & Economic factors $(f 23)$ \\
\hline & & Customs and bureaucracy (f24) \\
\hline & & Market saturation (f25) \\
\hline & & Quality standards (f26) \\
\hline & & Cultural factors (f27) \\
\hline & & Market infrastructure (f28) \\
\hline & & Political factors (f29) \\
\hline \multirow{4}{*}{ Internalization (I) } & \multirow{4}{*}{ Process } & Transaction costs (f30) \\
\hline & & Global partners/rivals (f31) \\
\hline & & Mode of market access (f32) \\
\hline & & Long-term relations (f33) \\
\hline
\end{tabular}

Source: own work

Figure 2 shows the network structure of the control hierarchy and dependencies among the factors and the sub-factors. Loops in services factors, market factors, firm factors and process factors indicate the inner dependencies among their own sub-factors. Arc from services factors to market factors indicates the outer dependence of sub-factors of market factors on the sub-factors of services factors. Similarly, there is an outer dependence between the firm factors and market factors. Feedbacks between the services factors-firm factors, firm factors-process factors, services factors-process factors and process factors-market factors show the interdependencies among these factors.

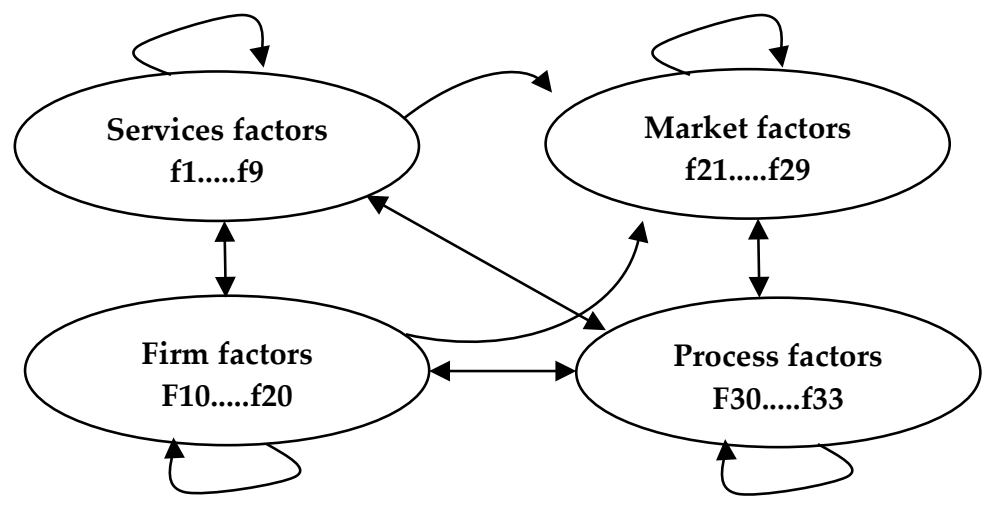

Figure 2. Control Hierarchy of the Study 


\section{T. Danacı Ünal - S. Özcan 12/4 (2020) 3991-4004}

Step 3: Performing paired comparisons

After determining the network structure, questionnaire forms were prepared in order to perform paired comparisons of the criteria (factors) and subcriteria (sub-factors) by using 1 to 9 fundamental scale of ANP (Table 3).

Table 3. Fundamental Scale of Absolute Numbers

\begin{tabular}{|c|c|c|}
\hline $\begin{array}{l}\text { Intensity of } \\
\text { Importance }\end{array}$ & Definition & Explanation \\
\hline 1 & Equal Importance & Two activities contribute equally to the objective \\
\hline 2 & Weak & \\
\hline 3 & Moderate importance & Experience and judgment slightly favor one activity over another \\
\hline 4 & Moderate plus & \\
\hline 5 & Strong importance & Experience and judgment strongly favor one activity over another \\
\hline 6 & Strong plus & \\
\hline 7 & $\begin{array}{l}\text { Very strong or demonstrated } \\
\text { importance }\end{array}$ & $\begin{array}{l}\text { An activity is favored very strongly over another; its dominance demonstrated in } \\
\text { practice }\end{array}$ \\
\hline 8 & Very, very strong & \\
\hline 9 & Extreme importance & The evidence favoring one activity over another is of the highest possible order of \\
\hline
\end{tabular}

Source: Saaty and Vargas, 2013: 3

Step 4: Determining Priority Vectors and Consistency Ratio (CR)

A priority vector derived from paired comparisons indicates the influences of factors on any factor in the network structure (Saaty and Vargas, 2013). Furthermore, Saaty and Vargas (2013) recommend that CR below $10 \%$ is acceptable and shows consistency between comparisons.

Table 4. Priority Vectors and Consistency Ratio (CR)

\begin{tabular}{|c|c|c|c|c|c|c|c|c|c|c|c|c|}
\hline \multirow[b]{2}{*}{ Influenced fact. } & \multicolumn{3}{|c|}{ Influencing services fact. } & \multicolumn{3}{|c|}{ Influencing firm fact. } & \multicolumn{3}{|c|}{ Influencing market fact. } & \multicolumn{3}{|c|}{ Influencing process fact. } \\
\hline & $F$ & $W$ & CR & $\mathbf{F}$ & $W$ & $\mathrm{CR}$ & $\bar{F}$ & $W$ & CR & $\bar{F}$ & $W$ & $\mathrm{CR}$ \\
\hline f1 & f9 & 0,20 & 0,05 & f18 & 0,16 & 0,03 & $\mathrm{f} 29$ & 0,18 & 0,02 & $\mathrm{f} 31$ & 0,30 & 0,02 \\
\hline f2 & f9 & 0,27 & 0,03 & $\mathrm{f} 18$ & 0,15 & 0,03 & $\mathrm{f} 23$ & 0,50 & 0,00 & $\mathrm{f} 33$ & 0,49 & 0,05 \\
\hline f3 & f9 & 0,18 & 0,03 & f18 & 0,14 & 0,02 & $\mathrm{f} 28$ & 0,16 & 0,02 & $\mathrm{f} 33$ & 0,30 & 0,02 \\
\hline $\mathrm{f4}$ & f8 & 0,22 & 0,02 & f18 & 0,12 & 0,03 & $\mathrm{f} 28$ & 0,14 & 0,01 & $\mathrm{f} 33$ & 0,35 & 0,02 \\
\hline $\mathrm{f5}$ & $\mathrm{f} 8$ & 0,19 & 0,02 & f19 & 0,14 & 0,02 & $\mathrm{f} 24, \mathrm{f} 26$ & 0,16 & 0,01 & $\mathrm{f} 31$ & 0,30 & 0,02 \\
\hline$f 6$ & $\mathrm{f} 8$ & 0,19 & 0,05 & f18 & 0,15 & 0,02 & $\mathrm{f} 28$ & 0,19 & 0,02 & $\mathrm{f} 31$ & 0,41 & 0,05 \\
\hline f7 & f9 & 0,23 & 0,05 & f16 & 0,16 & 0,02 & $x$ & $x$ & $x$ & $x$ & $x$ & $x$ \\
\hline f8 & f9 & 0,16 & 0,03 & f16 & 0,14 & 0,01 & $\mathrm{f} 24, \mathrm{f} 28$ & 0,15 & 0,02 & $\mathrm{f} 31, \mathrm{f} 33$ & 0,40 & 0,00 \\
\hline f9 & $\mathrm{f} 8$ & 0,18 & 0,03 & f18 & 0,15 & 0,02 & $\mathrm{f} 28$ & 0,17 & 0,02 & $\mathrm{f} 31$ & 0,35 & 0,02 \\
\hline f10 & $\mathrm{f} 3$ & 0,30 & 0,02 & f11 & 0,19 & 0,01 & $\mathrm{f} 23$ & 0,41 & 0,05 & $\mathrm{f} 31, \mathrm{f} 33$ & 0,50 & 0,00 \\
\hline f11 & f9 & 0,15 & 0,02 & f19 & 0,12 & 0,02 & $\mathrm{f} 28$ & 0,16 & 0,01 & $\mathrm{f} 30$ & 0,41 & 0,05 \\
\hline f12 & $\mathrm{f} 8$ & 0,30 & 0,02 & f18 & 0,17 & 0,03 & $\mathrm{f} 23, \mathrm{f} 28$ & 0,33 & 0,00 & $\mathrm{f} 31, \mathrm{f} 33$ & 0,50 & 0,00 \\
\hline f13 & $\mathrm{f} 5$ & 0,14 & 0,05 & f18 & 0,16 & 0,02 & $x$ & $x$ & $x$ & $\mathrm{f} 31, \mathrm{f} 33$ & 0,50 & 0,00 \\
\hline f14 & $x$ & $x$ & $x$ & $x$ & $x$ & $x$ & $x$ & $x$ & $x$ & $\mathrm{f} 32$ & 0,67 & 0,00 \\
\hline f15 & $\mathrm{f} 8$ & 0,40 & 0,02 & $\mathrm{f} 17, \mathrm{f} 18, \mathrm{f} 19$ & 0,14 & 0,01 & $x$ & $x$ & $x$ & $\mathrm{f} 31$ & 0,67 & 0,00 \\
\hline f16 & $\mathrm{f} 8$ & 0,32 & 0,05 & f18 & 0,23 & 0,01 & $\mathrm{f} 28$ & 0,14 & 0,01 & $\mathrm{f} 30, \mathrm{f} 31, \mathrm{f} 33$ & 0,33 & 0,00 \\
\hline f17 & $x$ & $x$ & $x$ & $x$ & $x$ & $x$ & $x$ & $x$ & $x$ & $\mathrm{f} 31, \mathrm{f} 33$ & 0,50 & 0,00 \\
\hline f18 & f9 & 0,28 & 0,02 & $\mathrm{f} 16, \mathrm{f} 17, \mathrm{f} 19$ & 0,13 & 0,02 & $\mathrm{f} 23$ & 0,19 & 0,01 & $\mathrm{f} 31, \mathrm{f} 33$ & 0,50 & 0,00 \\
\hline f19 & $x$ & $x$ & $x$ & $\mathrm{f} 13, \mathrm{f} 14, \mathrm{f} 15$ & 0,33 & 0,00 & $x$ & $x$ & $x$ & $\mathrm{f} 31, \mathrm{f} 33$ & 0,50 & 0,00 \\
\hline f20 & $\mathrm{f} 5$ & 0,19 & 0,02 & $\mathrm{f} 18$ & 0,14 & 0,02 & $x$ & $x$ & $x$ & $x$ & $x$ & $x$ \\
\hline f21 & $x$ & $x$ & $x$ & $x$ & $x$ & $x$ & $\mathrm{f} 23, \mathrm{f} 24$ & 0,29 & 0,02 & $x$ & $x$ & $x$ \\
\hline f22 & $x$ & $x$ & $x$ & $x$ & $x$ & $x$ & $\mathrm{f} 23$ & 0,29 & 0,02 & $x$ & $x$ & $x$ \\
\hline $\mathrm{f} 23$ & $x$ & $x$ & $x$ & $x$ & $x$ & $x$ & $\mathrm{f} 29$ & 0,67 & 0,00 & $x$ & $x$ & $x$ \\
\hline f24 & $\mathrm{x}$ & $x$ & $x$ & $\mathrm{x}$ & $x$ & $x$ & $\mathrm{f} 21$ & 0,14 & 0,02 & $x$ & $x$ & $x$ \\
\hline f25 & $x$ & $x$ & $x$ & $\mathrm{x}$ & $x$ & $x$ & $\mathrm{f} 23, \mathrm{f} 29$ & 0,50 & 0,00 & $x$ & $x$ & $x$ \\
\hline $\mathrm{f} 26$ & $x$ & $x$ & $x$ & $x$ & $x$ & $x$ & $\mathrm{f} 24$ & 0,30 & 0,02 & $x$ & $x$ & $x$ \\
\hline $\mathrm{f} 27$ & $x$ & $x$ & $x$ & $x$ & $x$ & $x$ & $\mathrm{f} 23, \mathrm{f} 29$ & 0,50 & 0,00 & $x$ & $x$ & $x$ \\
\hline $\mathrm{f} 28$ & $x$ & $x$ & $x$ & $x$ & $x$ & $x$ & $\mathrm{f} 23$ & 0,67 & 0,00 & $x$ & $x$ & $x$ \\
\hline f29 & $x$ & $x$ & $x$ & $x$ & $x$ & $x$ & $\mathrm{f} 23, \mathrm{f} 27$ & 0,50 & 0,00 & $x$ & $x$ & $x$ \\
\hline $\mathrm{f30}$ & $\mathrm{f} 1, \mathrm{f} 2, \mathrm{f} 5$ & 0,33 & 0,00 & f16 & 0,21 & 0,03 & $\mathrm{f} 23, \mathrm{f} 24, \mathrm{f} 26, \mathrm{f} 29$ & 0,16 & 0,02 & $\mathrm{f} 32$ & 0,41 & 0,05 \\
\hline $\mathrm{f} 31$ & f8, f9 & 0,14 & 0,03 & f19 & 0,13 & 0,02 & $\mathrm{f} 28$ & 0,14 & 0,02 & $\mathrm{f} 30, \mathrm{f} 33$ & 0,50 & 0,00 \\
\hline f32 & $\mathrm{f} 8$ & 0,35 & 0,02 & f14 & 0,15 & 0,01 & $\mathrm{f} 29$ & 0,16 & 0,02 & $\mathrm{f} 30$ & 0,41 & 0,05 \\
\hline $\mathrm{f33}$ & f9 & 0,19 & 0,04 & f16 & 0,13 & 0,03 & f29 & 0,19 & 0,02 & $\mathrm{f} 30, \mathrm{f} 31$ & 0,50 & 0,00 \\
\hline
\end{tabular}

Source: own work (calculated by using Super Decisions program) 


\section{T. Danacı Ünal - S. Özcan 12/4 (2020) 3991-4004}

Table 4 shows the priority vectors (weights $-W$ ) of the most influential sub-factors $(F)$ on the others in each main criteria (factors) separately. Price (f1), for instance, is influenced the most by timeliness (f9) among services factors; technological infrastructure (f18) among firm factors; political factors (f29) among market factors and global partners/rivals (f31) among process factors with the weights of 20\%, 16\%, \%18 and 30\% respectively. Additionally, CR infers consistency between comparisons, $<0,10$ shows that the decision makers provide consistent data. Besides, as the other paired comparisons are checked for their degree of inconsistency, results show that all CR's $<0,10$ and accordingly the questionnaire forms are filled in consistently by the experts (Table 4). Furthermore, CR's below 10\% supports the reliability of the results.

\section{Step 5: Constructing Supermatrix}

Supermatrix (weighted) is obtained after combining the results of paired comparisons by weighting the sum of each column as 1 . In this case, all factors are considered as a single group, whether or not they are under different main criteria (factors). Accordingly, we are able to sort the weights of importance of all sub-factors on one sub-factor. Unlike Table 4, Table 5 shows the weights of factors affecting a factor in order. Price (f1), for example, is influenced most by timeliness (f9) with a weight of 0,0691 and least influenced by number of vehicles (f10) with a weight of 0,0164. Besides price (f1) is not affected by market saturation (f25).

Step 6: Calculating the Limit Supermatrix

After obtained weighted supermatrix, limit süpermatrix is calculated as shown in Table 6 . Each column of the limit supermatrix must contain the same values. These values show the weights obtained as a result of the comparison of the corresponding criteria (factor) in the vertical column. These results give the answer of the research questions by revealing which factor is how effective and important among all the other factors. 
Table 5. Supermatrix (weighted)

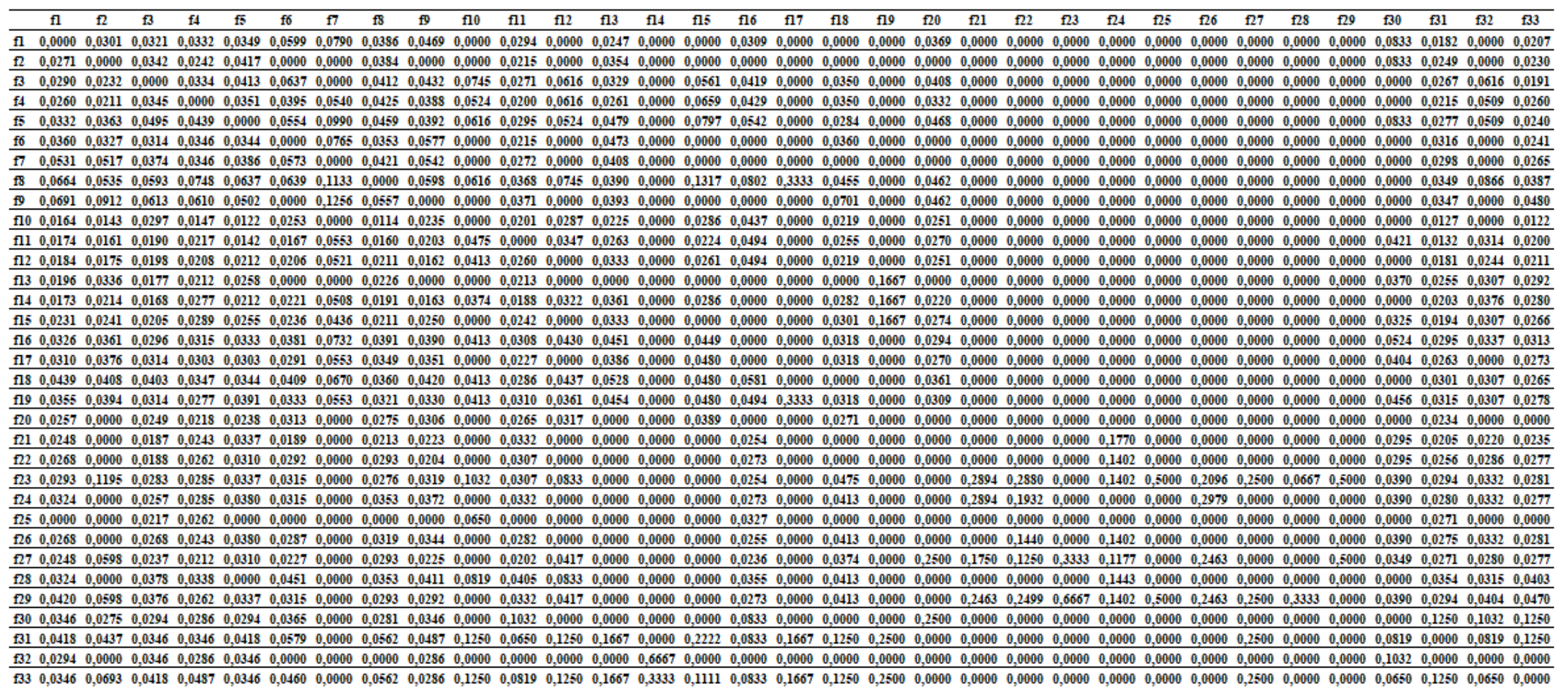

Source: own work (calculated by using Super Decisions program) 
Table 6. Limit Supermatrix

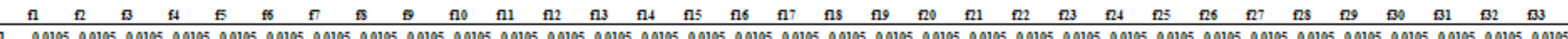

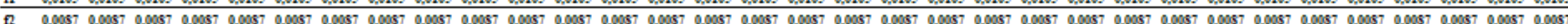

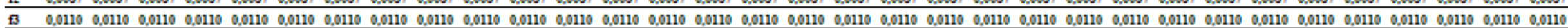

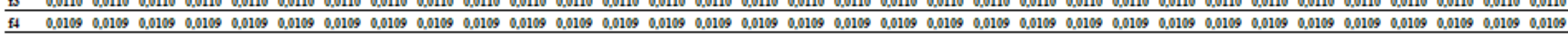

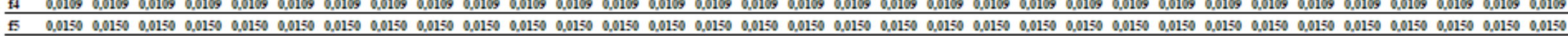

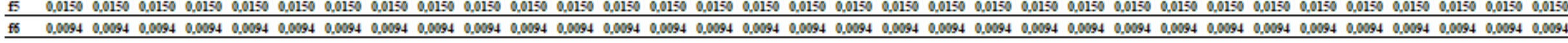

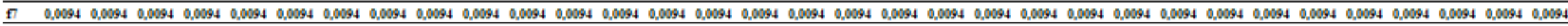

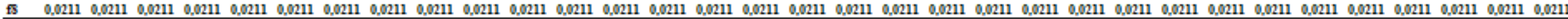

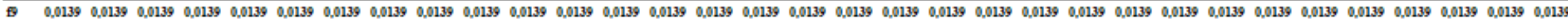

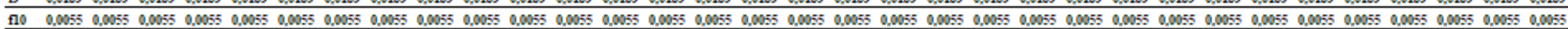

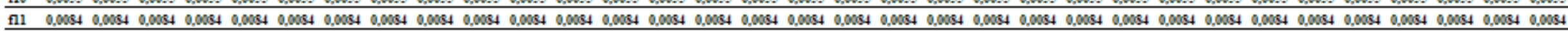

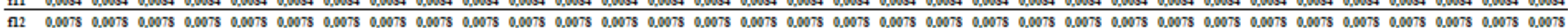

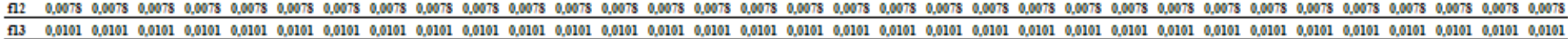

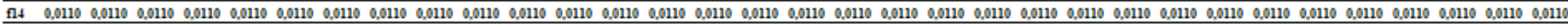

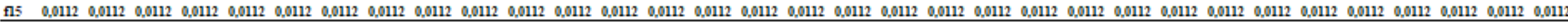

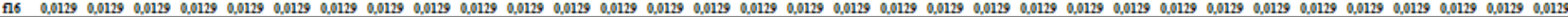

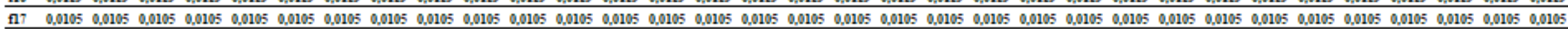

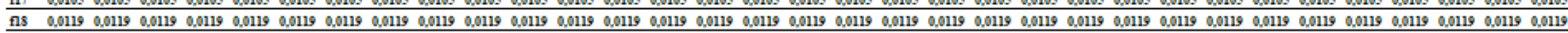

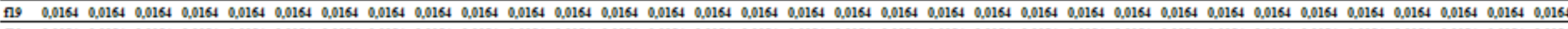

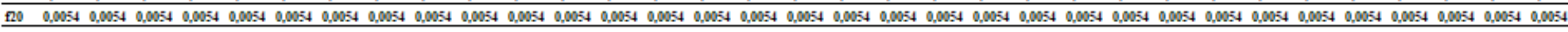

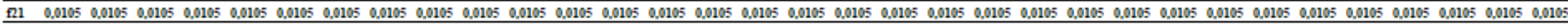

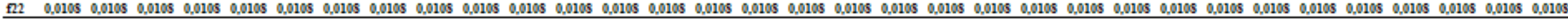

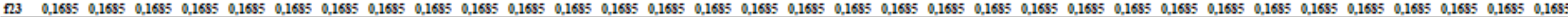

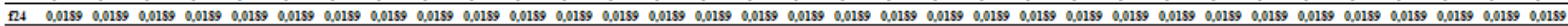

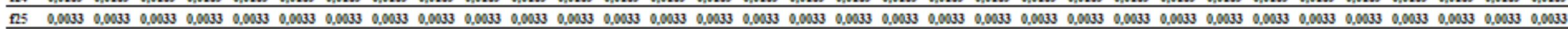

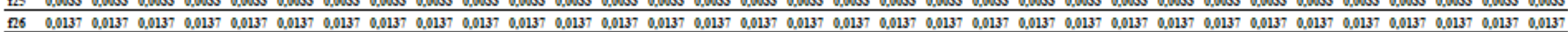

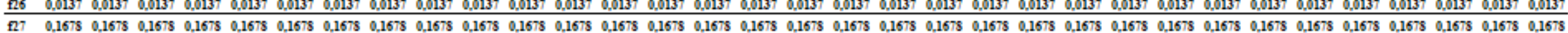

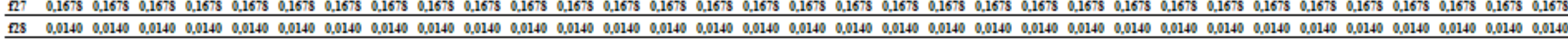

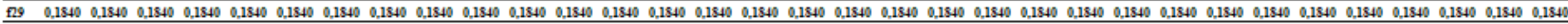

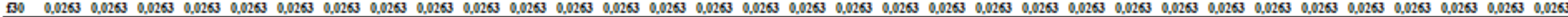

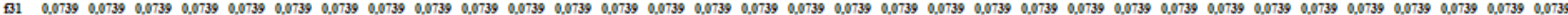
G

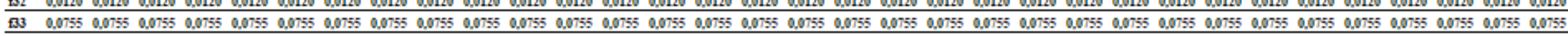

Source: own work (calculated by using Super Decisions program) 


\section{RESULTS}

The results obtained from the limit supermatrix show that the most effective sub-factors on internationalization processes of TPL providers are political factors $(0,1840)$, economic factors $(0,1685)$, cultural factors $(0,1678)$, long-term relations $(0,0755)$ and global partners/rivals $(0,0739)$; the least influencing factors are market saturation $(0.0033)$, number of employees $(0,0054)$ and number of vehicles $(0,0055)$ respectively (Table 6, Figure 3).

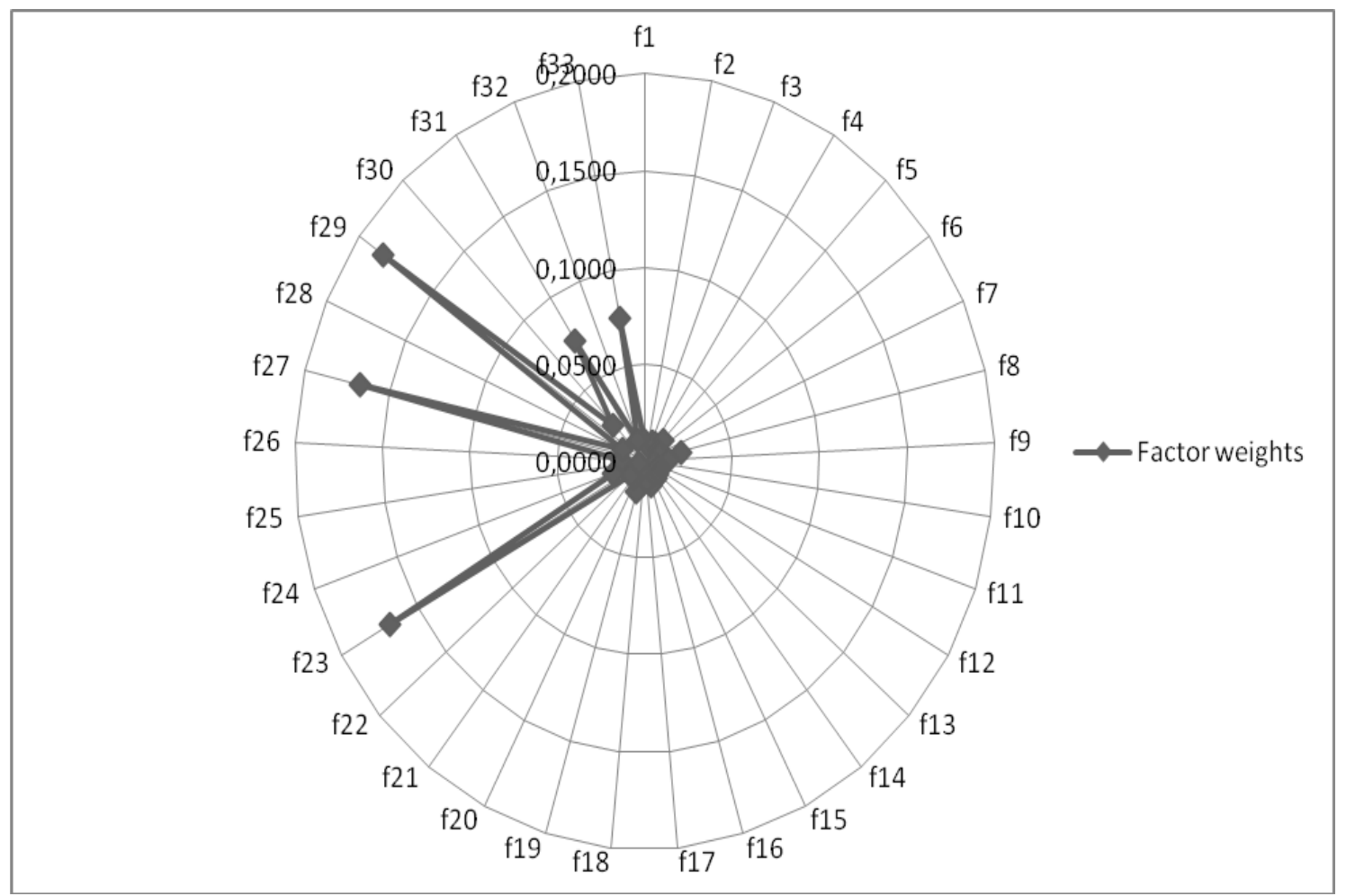

Figure 3. Weights of Factors

\section{Source: own work}

Since the most effective factors are political factors, economic factors, cultural factors, long-term relations and global partners/rivals, it is crucial to identify the sub-factors they are affected by. Results in Table 5 show that political factors are most influenced by economic factors and cultural factors; economic factors are most influenced by political factors; cultural factors are most influenced by economic factors, political factors, longterm relations and global partners/rivals; long-term relations are most influenced by global partners/rivals and transaction costs; global partners/rivals are most influenced by long-term relations and transaction costs.

The results of the study also indicate the importance ranking of sub-factors under each main factor. Table 7 shows that the most influential factors are customer focus (f8) in services factors; managers characteristics (f19) in firm factors; political factors (f29) in market factors and long-term relations (f33) in process factors. When we compare the main factors with respect to their total importance weights, it is revealed that market factors rank first, process factors rank second, firm factors rank third and services factors rank fourth. When we evaluate the main categories within the scope of the research model (OLI), it is found out that factors related to Location $(0,5914)$, Ownership $(0,2209)$ and Internalization $(0,1877)$ are effective in the internationalization processes of TPL service providers, respectively (Table 7). 
T. Danacı Ünal - S. Özcan 12/4 (2020) 3991-4004

Table 7. Weights of Factors and Sub-factors

\begin{tabular}{|c|c|c|c|c|c|c|c|c|c|c|c|c|}
\hline & Services & factors & & & & & & & & & & \\
\hline Factors & f1 & $\mathrm{f} 2$ & f3 & $\mathrm{f} 4$ & f5 & f6 & f7 & f8 & f9 & & & Total \\
\hline Weight & 0,0105 & 0,0087 & 0,0110 & 0,0109 & 0,0150 & 0,0094 & 0,0094 & 0,0211 & 0,0139 & & & 0,1097 \\
\hline \multirow[t]{2}{*}{ Rank } & 22 & 28 & 18 & 20 & 10 & 26 & 27 & 7 & 12 & & & \\
\hline & Firm & factors & & & & & & & & & & \\
\hline Factors & $\mathrm{f} 10$ & $\mathrm{f} 11$ & f12 & f13 & f14 & f15 & f16 & $\mathrm{f} 17$ & f18 & f19 & $\mathrm{f} 20$ & Total \\
\hline Weight & 0,0055 & 0,0084 & 0,0078 & 0,0101 & 0,0110 & 0,0112 & 0,0129 & 0,0105 & 0,0119 & 0,0164 & 0,0054 & 0,1111 \\
\hline \multirow[t]{2}{*}{ Rank } & 31 & 29 & 30 & 25 & 19 & 17 & 14 & 23 & 16 & 9 & 32 & \\
\hline & Market & factors & & & & & & & & & & \\
\hline Factors & $\mathrm{f} 21$ & $\mathrm{f} 22$ & f23 & f24 & f25 & f26 & $\mathrm{f} 27$ & f28 & f29 & & & Total \\
\hline Weight & 0,0105 & 0,0108 & 0,1685 & 0,0189 & 0,0033 & 0,0137 & 0,1678 & 0,0140 & 0,1840 & & & 0,5914 \\
\hline \multirow[t]{2}{*}{ Rank } & 24 & 21 & 2 & 8 & 33 & 13 & 3 & 11 & 1 & & & \\
\hline & Process & factors & & & & & & & & & & \\
\hline Factors & $\mathrm{f} 30$ & $\mathrm{f} 31$ & $\mathrm{f} 32$ & $\mathrm{f} 33$ & & & & & & & & Total \\
\hline Weight & 0,0263 & 0,0739 & 0,0120 & 0,0755 & & & & & & & & 0,1877 \\
\hline Rank & 6 & 5 & 15 & 4 & & & & & & & & \\
\hline TOTAL & & & & & & & & & & & & 1,000 \\
\hline
\end{tabular}

\section{CONCLUSION AND DISCUSSIONS}

This study develops a conceptual model concerning the influencing factors on the internationalization process of TPL service providers differently from the studies (Javalgi et al., 2003; Javalgi and Grossman, 2014) address the internationalization of the services based on OLI advantages of Dunning Eclectic Paradigm.

Ownership $(O)$ advantages of the conceptual model cover the TPL providers' unique resources which are divided into services related (price, capacity, speed, customer focus, etc.) and firm related (number of employees, number of vehicles, infrastructure, managers, etc.) characteristics. We find out that being customer focused, specialization and making the shipments/deliveries on time are more effective than other services factors. Similarly, management characteristics, logistics networks and technological infrastructure are crucial for international logistics operations. Unlike many studies (Javalgi et al., 2003; Cicic et al., 1999) argue that firm characteristics such as firm size and managerial characteristics have impacts on the internationalization process of services, we suppose that firm size will not be an effective factor due to the technological development but managerial decisions still maintain their importance for the TPL providers. As previously stated that the number of vehicles is determined as one of the least effective factors on the internationalization process of TPL. We explain this case as a consequence of outsourcing. Today many logistics companies supply the vehicles from outside rather than having their own fleet of vehicles in order to minimize their costs. Moreover, the customers focus on the quality of service and how easily they access information rather than the number of vehicles or employees. We argue that a good international logistics management would be carried out thanks to a good international management mentality and technological infrastructure based on co-created and developed computer and tracking systems.

We assume that Location ( $L$ ) advantages in the model should not only involve the foreign markets but also domestic markets. Therefore, we add factors that influence both of these two markets. While most studies focus on firm characteristics, we concentrate on market characteristics as strong factors. Some studies argue that the impact of government regulations is low (Mitra and Bagchi, 2008) while others find that it is highly important (Rahman et al., 2019) for the TPL providers. In this study, results support that customs and bureaucracy are still forceful factors for the international logistics operations in Turkey. Besides, we identify the political factors that shape foreign relations and trade between countries, as the most influential factors. We assume the political factors as 'zero element' of international logistics activities. If there are trade restrictions and limitations between two countries, other factors affecting the internationalization process will lose their importance. 


\section{T. Danacı Ünal - S. Özcan 12/4 (2020) 3991-4004}

We find that the first three effective factors (political factors, cultural factors and economic factors) have approximate importance weights. This finding indicates that the impacts of these three factors on international logistics activities of TPL are close and high. The fact that all three sub-factors are involved in the market factors proves the crucial roles of both domestic and foreign markets in international logistics. These results also support today's economic relations among countries. Countries that have problems with their bilateral relations, firstly suspend commercial and logistics activities among each other and this process is followed by changes in the economic environment. Therefore we emphasize that long-term international logistics activities depend on long-term and stable political and economic relations.

Another aspect of this study that differs from other studies is related to Internalization (I) advantages. We determine that global partners of a firm and their long term relations have an important impact on making a firm internalize its own advantages internationally. We support that a TPL service provider's networks with its global partners strongly affect its internationalization process, similar to many studies (Lemoine and Dagnæs, 2003; Lommelen et al., 2002; Hertz and Alfredsson, 2003 ) in the literature.

Logistics services increase their shares in total service exports both in the world and in Turkey. Accordingly, the development of logistics service exports and the determination of obstacles for the internationalization of TPL service providers are crucial. However existing literature isn't sufficient to reveal the certain drivers of internationalization of TPL service providers. Previous studies focused on few factors and address the problem in a limited scope. Additionally, there is no consensus among them other than a few factors such as networks, technology, customer relations and rules and regulations. With this study, it is aimed to cover these gaps by considering the factors from a broader perspective. It is assumed that the findings will contribute to both academic and sectoral environment. Since this study is limited to TPL service providers operating in Turkey, the results of the study can be improved by future studies concerning different service providers operating in different regions.

\section{REFERENCES}

Boehe, D. M. (2016). The Internationalization of Service Firms From Emerging Economies: An Internalization Perspective, Long Range Planning, 49(5), 559-569.

Brock, D. M. and Alon, I. (2009). Internationalization of Professional Service Firms, International Business: Research Teaching and Practice, 3(1), 52-70.

Cicic , M., Patterson, P. G. and Shoham, A. (1999). A Conceptual Model of the Internationalization of Services Firms, Journal of Global Marketing, 12(3), 81-106.

Coviello, N. E. and Martin, K. A. M. (1999). Internationalization of Service SMEs: An Integrated Perspective From The Engineering Consulting Sector, Journal of International Marketing, 7 (4), 42-66.

Dunning, J. H. (1988). The Eclectic Paradigm of International Production: A Restatement and Some Possible Extensions, Journal of International Business Studies, Spring , 1-31.

Erramilli, K. M. (1990). Entry Mode Choice in Service Industries, International Marketing Review, 7(5), 50-62.

Ferreira, M. P., Pinto, C., Serra, F. and L. Filipe (2011). John Dunning's Influence in International Business/Strategy Research: A Bibliometric Study in the Strategic Management Journal, Journal of Strategic Management Education, 7(2), 1-24.

Freeman, S. and Sandwell, M. (2008). Professional Service Firms Entering Emerging Markets: The Role of Network Relationships, Journal of Services Marketing, 22(3), 198-212.

Hertz, S. (1993). The Internationalization Processes of Freight Transport Companies. Towards A Dynamic Network Model of Internationalization. Thesis (Ph. D.). The Economic Research Institute. Stockholm School of Economics. Stockholm.

Hertz, S. and Alfredsson, M. (2003). Strategic Development of Third Party Logistics Providers, Industrial Marketing Management, 32, 139-149.

Javalgi, R. G., Griffith, D. A., and White D. S. (2003). An Empirical Examination of Factors Influencing the Internationalization of Service Firms, Journal of Services Marketing, 17(2), 185 - 201. 
T. Danacı Ünal - S. Özcan 12/4 (2020) 3991-4004

Javalgi, R. G. and Grossman, D. A. (2014). Firm Resources and Host-Country Factors Impacting Internationalization of Knowledge-Intensive Service Firms, Thunderbird International Business Review, 56(3), 285-300.

Javalgi, R. G. and Martin, C. L. (2007). Internationalization of Services: Identifying the Building-Blocks for Future Research, Journal of Services Marketing, 21 (6), 391 - 397.

Lemoine, W. and L. Dagnæs. (2003). Globalisation Strategies and Business Organisation of a Network of Logistics Service Providers, International Journal of Physical Distribution and Logistics Management, 33(3). 209-228.

Lommelen, T., Matthyssens, P. and Pauwels, P. (2002). Accelerations in the Internationalization Process of Logistics Firms, in The European International Business Academy 28th Annual Meeting, Athens, Greece, 810 December 2002, 1-18.

Mitra, S. and Bagchi, P. K. (2008). Key Success Factors, Performance Metrics, and Globalization Issues in The Third-Party Logistics (3PL) Industry: A Survey of North American Service Providers, In Supply Chain Forum: An International Journal, 9 (1), 42-54.

Netland, T. H. and Alfnes, E. (2007). Internationalisation of Professional Services-A 1999-2005 literature review, in College of Service Operations 2007 Conference, 12-13 July 2007, 1-27.

Parasuraman, A., Zeithaml, V. A. and Berry, L. L. (1985). A Conceptual Model of Service Quality and its Implications for Future Research, The Journal of Marketing, 49 (Fall), 41-50.

Rahman, S., Ahsan, K., Yang, L. and Odgers, J. (2019). An Investigation into Critical Challenges for Multinational Third-Party Logistics Providers Operating in China, Journal of Business Research, 103, 607-619.

Saaty, T. L. (1999). Fundamentals of The Analytic Network Process. in Proceedings of The 5th International Symposium on The Analytic Hierarchy Process (ISAHP), Kobe, Japan, August 12-14, 1999, 1-14.

Saaty, T. L. (2004). Fundamentals of The Analytic Network Process-Dependence and Feedback in DecisionMaking with A Single Network, Journal of Systems Science and Systems Engineering, 13(2), 129-157.

Saaty, T. L., and Sodenkamp, M. (2008). Making Decisions in Hierarchic and Network Systems, International Journal of Applied Decision Sciences, 1(1), 24-79.

Saaty, T. L. and Vargas, L. G. (2006). Decision Making with Analytic Network Proces, America, Springer.

Saaty, T. L. and Vargas, L. G. (2013). Decision Making with the Analytic Network Process, Economic, Political, Social and Technological Applications with Benefits, Opportunities, Costs and Risks, International Series in Operations Research \& Management Science, volume 195, Boston, MA, Springer.

Tzeng, G. H. and Huang, J. J. (2011). Multiple Attribute Decision Making: Methods and Applications, CRC Press., US, Taylor \& Francis.

Vargo, S. L. and Lusch, R. F. (2004). Evolving to A New Dominant Logic for Marketing, Journal of Marketing, 68(1), 1-17.

Yıldırım, A. and H. Şimşek. (2011). Sosyal Bilimlerde Nitel Araştırma Yöntemleri, Ankara, Seçkin Yayıncılık.

Zeithaml, V. A., Parasuraman, A. and L. L. Berry (1985). Problems and Strategies in Services Marketing, The Journal of Marketing, 49 (Spring), 33-46. 